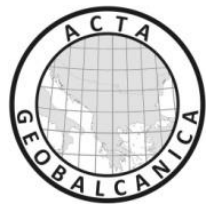

\title{
GIS METHODS FOR ASSESSMENT OF HYDROGEOMORPHIC RISK AND ANTHROPOGENIC IMPACT WHICH AFFECT THE ARCHAEOLOGICAL SITES. CASE STUDY: DEALUL MARE ARCHAEOLOGICAL SITE, MOLDAVIAN PLATEAU (ROMANIA)
}

\author{
Alin Mihu-Pintilie ${ }^{1}$, Andrei Asăndulesei ${ }^{1}$, \\ Cristian Constantin Stoleriu ${ }^{2} \&$ Gheorghe Romanescu $^{2}$ \\ ${ }^{1}$ Interdisciplinary Research Department - Field Science, Alexandru Ioan Cuza University of \\ Iași, Romania \\ ${ }^{2}$ Department of Geography, Faculty of Geography and Geology, Alexandru Ioan Cuza \\ University of Iași, Romania \\ Corresponding author: mihu.pintilie.alin@gmail.com
}

\begin{abstract}
On the territory of Moldova Plateau (Eastern Romania), the degradation of prehistoric archaeological sites is a major issue concerning their conservation. The intensification of soil erosion, actual geomorphological processes and human impact (agriculture, over-grazing, exploitation) are the main causes leading to their destruction. For this reason, different approaches and methods, from scientifical works, were used to assess the intensity of erosion in this region of the country, but most of them have focused only on soil degradation. This study proposes a GIS method, to evaluate not only hydrogeomorphological hazards but also human impact that affecting archaeological sites, which use multiple thematic layers quantified in a single evaluating system (Likerd-type scale). A risk map was generated on 1 sqkm extend and based on geoformula, which was adapted for a case study (Dealul Mare archaeological site). In calculation of this geoformula were inserted the following parameters: slope, the occurrence frequency for landslides based on aspect classes, potential water flow erosion depending on land use, potential soil types erosion, surface and liniar erosion, landslides and slope gravitational processes and human impact. The spatial analysis use a digital terrain model (DTM) with a high precision (0.25 sqm/pixel), based on LiDAR technology. Contrary to the traditional scientifical papers, characterized by subjectivity, in this study the detailed identification of risk areas was allowed by a largescale analysis. The proposed method can be applied to all archaeological sites, in Moldova Plateau, and also can be a tool for commencement of conservation works for archaeological sites which can be at risk of being destroyed.
\end{abstract}

Keywords: GIS, geoformula, risk map, archaeologic site, Moldavian Plateau.

\section{INTRODUCTION}

In present-day Romania, the conservation level evaluation of the intangible heritage, identified in situ, is a complex scientific approach and involves several research 
directions. The most important aspect, from physical and geographical perspective, is the quantification of anthropogenic impact and the geomorphological processes that shape the terrain surface inside the archaeological sites. The estimation of the archaeological material degradation level, due to erosion processes, is very important for achieving an in situ conservation plan or the rescue through invasive methods [1-4]. Thus, through GIS analysis technics, whithin this study we propose a model for assessing the conservation status of prehistoric archaeological sites and multi-layered archaeological complexes specific for Moldavian Plateau. The geoformula used to generate the risk map, integrates and details the following thematic layers: morphology and landforms, natural layer of conservation and the destructive context [3]. The analysis was adapted for a case study, which is representative for the studied area [5].

\section{CASE STUDY: DEALUL MARE ARCHAEOLOGICAL SITE}

The Dealul Mare eneolithic settlement (synonym - Dealul Boghiu; Dealul Mare Filiasi)

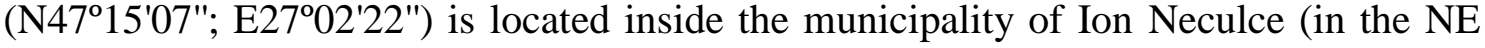
sector), Iasi county (Eastern Romania). The main administrative-territorial landmarks are: approx. $200 \mathrm{~m}$ south-west to Baltati municipality limit; approx. $0.8 \mathrm{~km}$ south to Belcesti municipality limit; approx. $0.5 \mathrm{~km}$ south to Filiasi village; approx. $1.5 \mathrm{~km}$ west to Podisu village. According the morphometry, achieved through direct and periegesis surveying, the site covers a relative area of $35012.48 \mathrm{sqm}$. It has a perimeter of $1024.00 \mathrm{~m}$ and it is located in the absolute altitude deviation between $170-185.72 \mathrm{~m}$ (Stereographic projection for Romania, 1970) [1, 2, 4 and 5]. In relation to the current level of the main watercourse in the area - the Valea Oii (left tributary of Bahluiet), the relative altitude is between $80-95 \mathrm{~m}$ and overlooks the interfluvial peaks from center area of Sârca Hills. The location of the site on the structural plateau, at the top of the ridge Dealul Mare $(185.72 \mathrm{~m})$, also provides a very good visibility both to the north and on the west-east alignment, given by the meanders of the Valea Oii river [3] (Fig. 1).

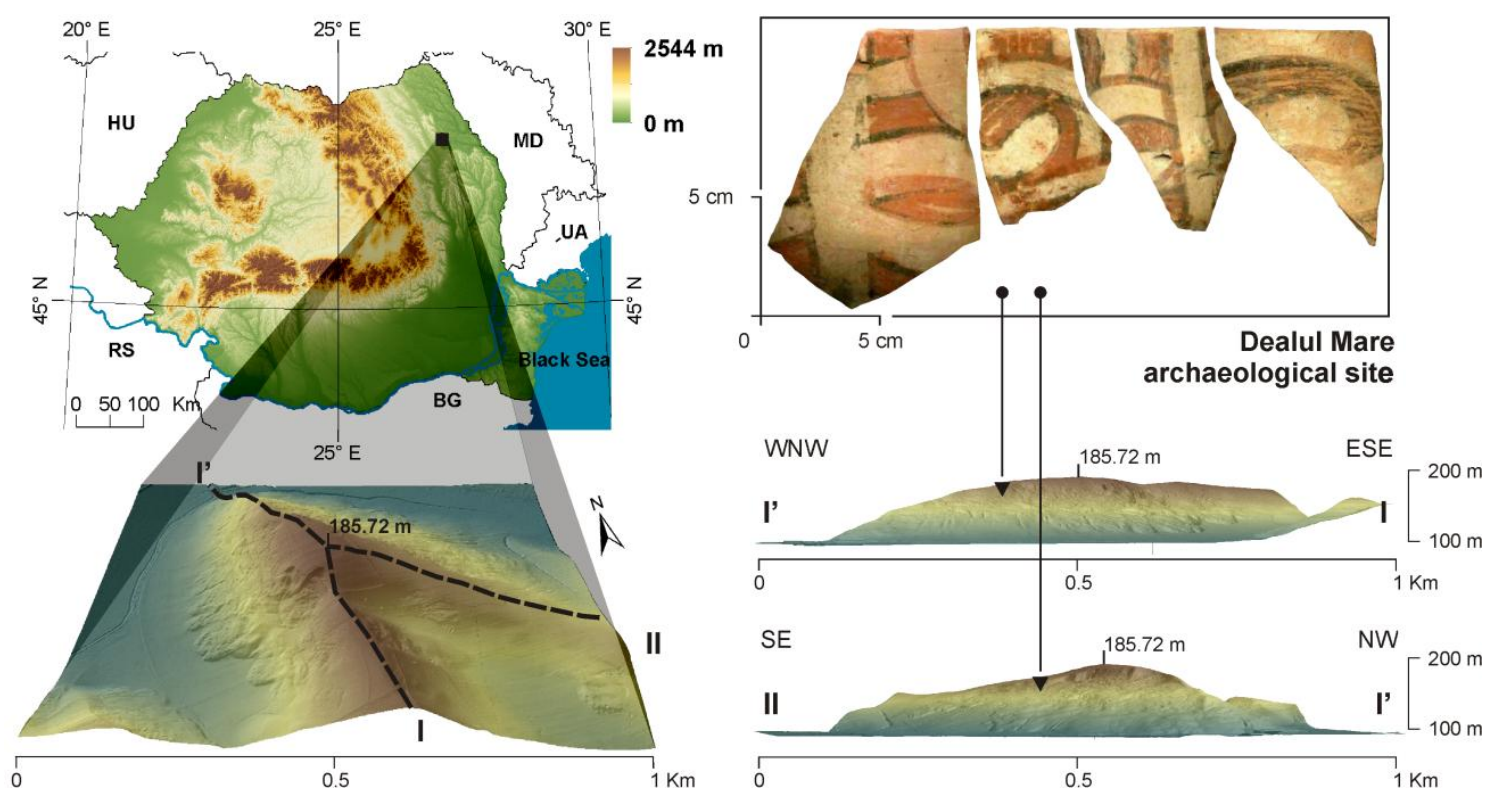

Figure 1: Geographic location of the Dealul Mare archaeological site on the territory of Moldavian Plateau (Romania). In the corner box - fragments of pottery (Cucuteni-Trypillian culture) found on the slopes affected by erosion 
The relief's evolution is the result of morphosculpture generated by hydrographic network, over the monocline structure area. Draining direction of NW-SE, specific to the consequent valleys of Moldova Plateau, generates a cuesta relief with level 1 of asymmetry [3]. The ancient settlement occupies a cuesta, modeled by the Valea Oii on the west, north-west and north sides [1, 2 and 5]. Eastern and South-Eastern slopes are shaped by a regressive erosion of a torrential valley, captured in time by the main collector. Current morphology is a product of both natural factors (surface erosion, ravines, landslides) and the anthropogenic factors (construction fish ponds, agrolivestock activity) [3].

Analyzing the perimeter around Dealul Mare archeological site, on 1 sqkm area, drainage depth exceeding $100 \mathrm{~m} / \mathrm{sqkm}$. The slopes oriented to west, north and northeast, which flanking Dealul Mare ridge, are heavily affected by landslides, and their declivity often exceeds $30-35^{\circ}$. The slopes are shaped by gravitational processes, numerous gullies and drainage canals. These processes are initiated by liniar surface runoff. Also, lot of coastal springs appear at the bottom of slopes, and are responsable for generating the torrential drainage ditches. The south-eastern versant is a connection between structural plateau (where the ancient settlement is located) and interfluvial ridge (the watershed limit between Valea Oii and Bahluiet). This sector is least affected by the actual geomorphological processes. In the south side, the link between structural plateau and interfleuves is very narrow $(3-5 \mathrm{~m})$, and strongly affected by landslides.

\section{METHODS AND TECHNIQUES}

The geospatial database, used for this study, contains a digital terrain model (DTM) based on LiDAR technology [6 and 7], with a resolution of $0.25 \mathrm{sqm} /$ pixel (Fig. 2). Also, DTM was refined with measurements effected in terrain, using a Leica TCR 1200 total station and a Leica GPS System 1200. Firstly, the DTM has been used for mapping the areas with archaeological material. These archaeological material has been identified and mapped using multiple periegesis, topographic measurements and geophysical prospecting (cesium and fluxgate Magnetometry) [1-5] (Fig. 2b). The thematic maps necessary for this study are: hypsometry (Fig.2a), slope and aspect (Fig.2c,b), potential drainage network, geomorphological processes, soil texture, and these have been made using GIS software (ArcGIS v.10.2 - using Spatial Analyst Tools) (Fig.2g) [3, 4].

For the analysis of conservation natural layer of the site was identified the soil texture, vegetation type and land use. The vector layer corresponding to soil types has been digitized in Microimage TNTMips v.6.9 software, and was based on soil maps located in Targu Frumos area [8]. The soil erodability degree was determined based on standard methodology used for analyzing the ecopedological indexes (Fig.2f) [9]. For digitizing the layer with land use have been used the ortophotoplans (ed. 2006 and 2012). The land use map was integrated in calculation of water erodability index using the standard methodology [9] (Fig.2e). The resulted maps (soil erodability degree, water erodability index) have been rasterized using Raster Interpolation function (Fig. 2e,f).

For outlining of destructive context of archaeological site, were mapped the geomorphological processes, such as: surface and linear erosion, landslides and slope gravitational processes (Fig. 2g) and anthropogenic interventions - recent excavation, military trenches, bomb craters and sheep breeding activity (Fig.2h) . For their mapping were used: DTM, ortophotoplans (ed. 2006 and 2012) (Fig. 2b) and aerial photographs 
[1, 2 and 5]. The vector layers were rasterized using GIS capabilities (Raster Interpolation function) (Fig. 2g,h) [3].
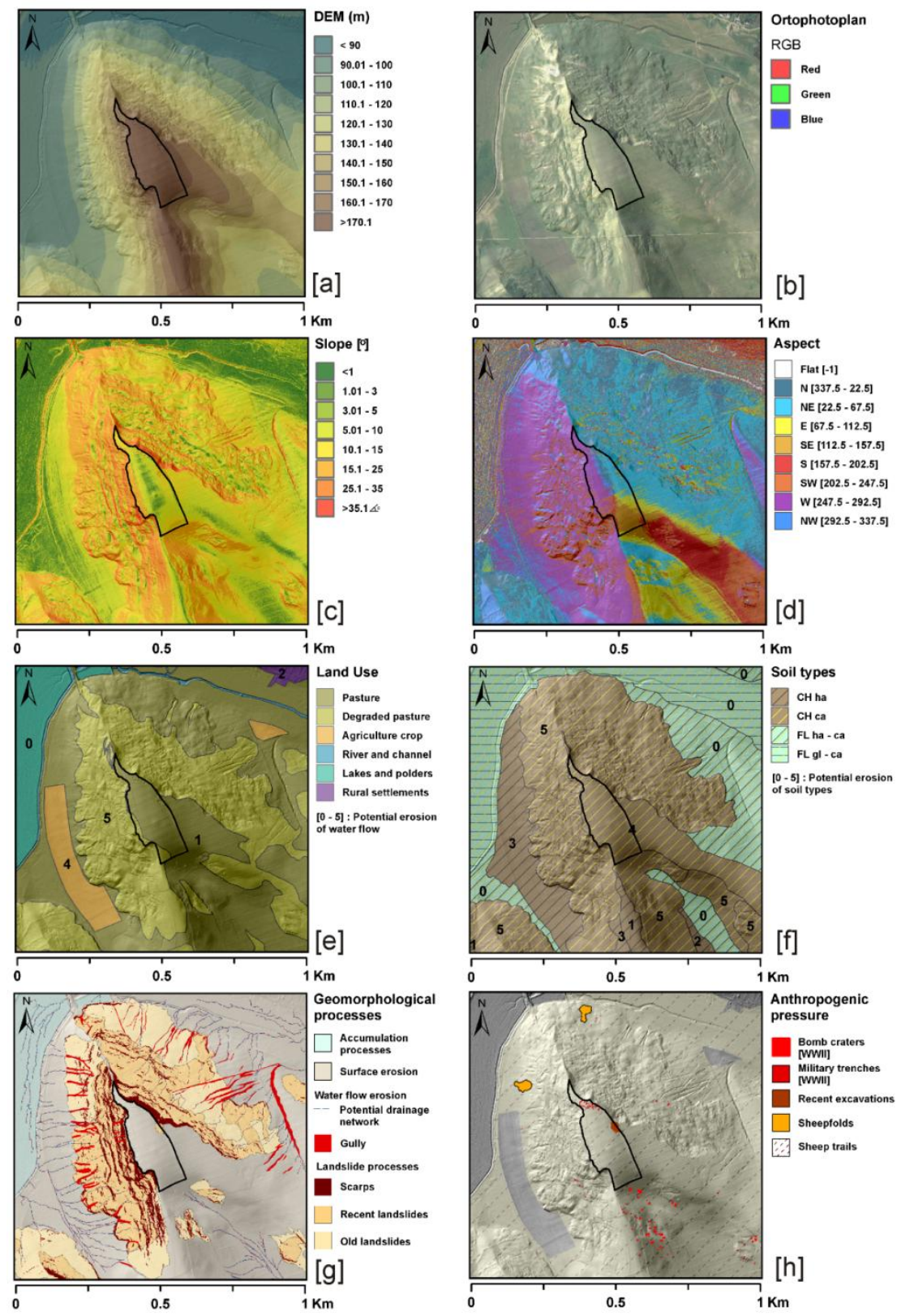

Figure 2: Thematic layers integrated in the geoformula applied for the risk map of Dealul Mare archeological site: [a] Digital elevation model; [b] Ortophotos ed. 2012; [c] Slope; [d] Aspect;

[e] Land Use; [f] Soil types; [g] Geomorphological processes; [h] Anthropogenic pressure

In order to quantify, in an ordinal system codification, has been used the ranking method [11], which consist to granting the scores for each indicator, with scores between 0-5, wherein:

$0=$ null; 1 = non-degraded; 2 = low; 3 = medium; 4 = high; 5 = very high; (Table 1 ).

Thereafter, the new thematic rasters, obtain from ranking method, have been inserted into geoformula, necessary for calculate and generate the hydrogeomorphic risk and 
anthropogenic impact map. The geoformula (Eq. 1) consist in summation of eight ranked rasters, using Map Algebra Function (ArcGIS):

Eq. 1 Degradation severity raster = ["slope" + "slope aspect" + "land use" + "soil types" + "surface erosion" + "linear erosion" + "landslide processes" + "anthropogenic impact"] / 8 (Fig. 3).

Table 1: Assigning the degradation severity for Dealul Mare archaeological site, for each thematic vector layer, using ranking method, on $1 \mathrm{sqkm}$ extend

\begin{tabular}{|c|c|c|c|c|}
\hline $\begin{array}{l}\text { Degradation } \\
\text { types }\end{array}$ & GIS layer & $\begin{array}{l}\text { Value, relative frequency or } \\
\text { type of erosion process }\end{array}$ & $\begin{array}{r}\text { Surface } \\
{[\text { ha] }}\end{array}$ & $\begin{array}{l}\text { Degradation severity } \\
\text { (ranking method)* }\end{array}$ \\
\hline \multirow{11}{*}{ 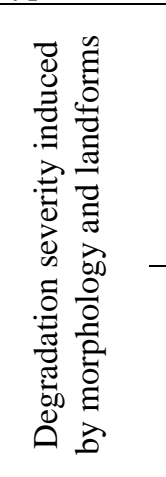 } & \multirow{6}{*}{$\begin{array}{r}\text { Slope [Fig.2c] } \\
\text { Degree }\end{array}$} & $<1.00$ & 3.39 & 0 \\
\hline & & $1.01-5$ & 22.88 & 1 \\
\hline & & $5.01-10$ & 25.83 & 2 \\
\hline & & $10.01-25$ & 45.06 & 3 \\
\hline & & 25.01-35 & 5.57 & 4 \\
\hline & & $>35.01$ & 0.65 & 5 \\
\hline & \multirow{5}{*}{$\begin{array}{r}\text { Aspect [Fig.2d] } \\
\text { Landslide density for } \\
\text { slope aspect in } \\
\text { Moldavian Plateau } \\
\text { [10] }\end{array}$} & Flat & 1.93 & 0 \\
\hline & & $N W-N-N E$ & 33.22 & 5 \\
\hline & & $\mathrm{NE}-\mathrm{E}-\mathrm{SE}$ & 24.09 & 3 \\
\hline & & $\mathrm{SE}-\mathrm{S}-\mathrm{SW}$ & 12.85 & 4 \\
\hline & & $\mathrm{SW}-\mathrm{W}-\mathrm{NW}$ & 31.32 & 2 \\
\hline \multirow{9}{*}{ 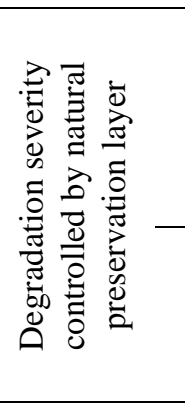 } & \multirow{5}{*}{$\begin{array}{r}\text { Land use [Fig. 2e] } \\
\text { Potential erosion of } \\
\text { water flow [9] }\end{array}$} & Lakes and polders & 7.87 & 0 \\
\hline & & Pasture & 48.54 & 1 \\
\hline & & Rural settlements & 1.13 & 2 \\
\hline & & Agriculture crop & 5.49 & 4 \\
\hline & & Degraded pasture & 40.38 & 5 \\
\hline & \multirow{4}{*}{$\begin{array}{r}\text { Soil types [Fig.2f] } \\
\text { Potential erosion of } \\
\text { soil texture [8 and 9] }\end{array}$} & FL ha $-\mathrm{ca} / \mathrm{FL} \mathrm{gl}-\mathrm{ca}$ & 33.85 & 0 \\
\hline & & $\mathrm{CH}$ ha & 2.2 & $1-2$ \\
\hline & & $\mathrm{CH}$ ha (eroaded) & 19.25 & $3-4$ \\
\hline & & $\mathrm{CH}$ ca (eroaded) & 47.93 & 5 \\
\hline \multirow{12}{*}{ 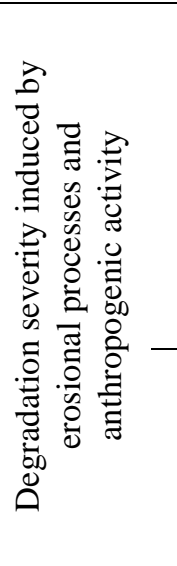 } & \multirow{7}{*}{$\begin{array}{l}\text { Geomorphological } \\
\text { processes [Fig.2g] }\end{array}$} & Accumulation & 16.89 & 0 \\
\hline & & Surface erosion & 86.53 & 1 \\
\hline & & $\begin{array}{r}\text { Liniar erosion } \\
\text { (potential drainage network) }\end{array}$ & 0.30 & 2 \\
\hline & & Gully & 2.91 & 5 \\
\hline & & Scarps & 5.60 & 5 \\
\hline & & Recent landslides & 18.30 & 4 \\
\hline & & Old landslides & 16.65 & 3 \\
\hline & \multirow{5}{*}{$\begin{array}{l}\text { Anthropogenic } \\
\text { impact [Fig. 2h] }\end{array}$} & Bomb craters [WWII] & 0.19 & 4 \\
\hline & & Military trenches [WWII] & 0.08 & 4 \\
\hline & & Recent excavations & 0.09 & 5 \\
\hline & & Sheepfolds & 0.31 & 2 \\
\hline & & Sheep trails & 87.42 & 3 \\
\hline
\end{tabular}

*0: null; 1: non-degraded; 2: low; 3: medium; 4: high; 5: very high.

\section{RESULTS AND DISCUSSION}

The morphological context is given by relief's role as a control factor of erosion of natural layer of conservation of archaeological sites. It intervenes in erosion processes' dynamics and occurence, through a variety of parameters, which can be differently interpreted, depending on the scale of analysis. Of these, the slope has a decisive influence on erosion processes, both by adjusting the ratio of surface runoffs/infiltration, 
and by a gradually potentiating for pluvial-denudation or for modification of water runoff [3]. For the area of Dealul Mare archaeological site, the slope is between $0-89^{\circ}$, the dominant slope class being between $10-25^{\circ}(45.06 \%)$. Also, although the slope aspect is not a decisive factor in the equation of hydro-geomorphological risk quantification, this parameter was used as a predictive indicator for developing slope processes, which are typical for cuesta's escarpment whithin Moldova Plateau [10]. Thus, the most affected slopes by geomorphological processes are those with N-NE and S-SW slope exposure. In this study area, these classes cumulate $46.07 \%$ of the total area of $1 \mathrm{sqkm}$.

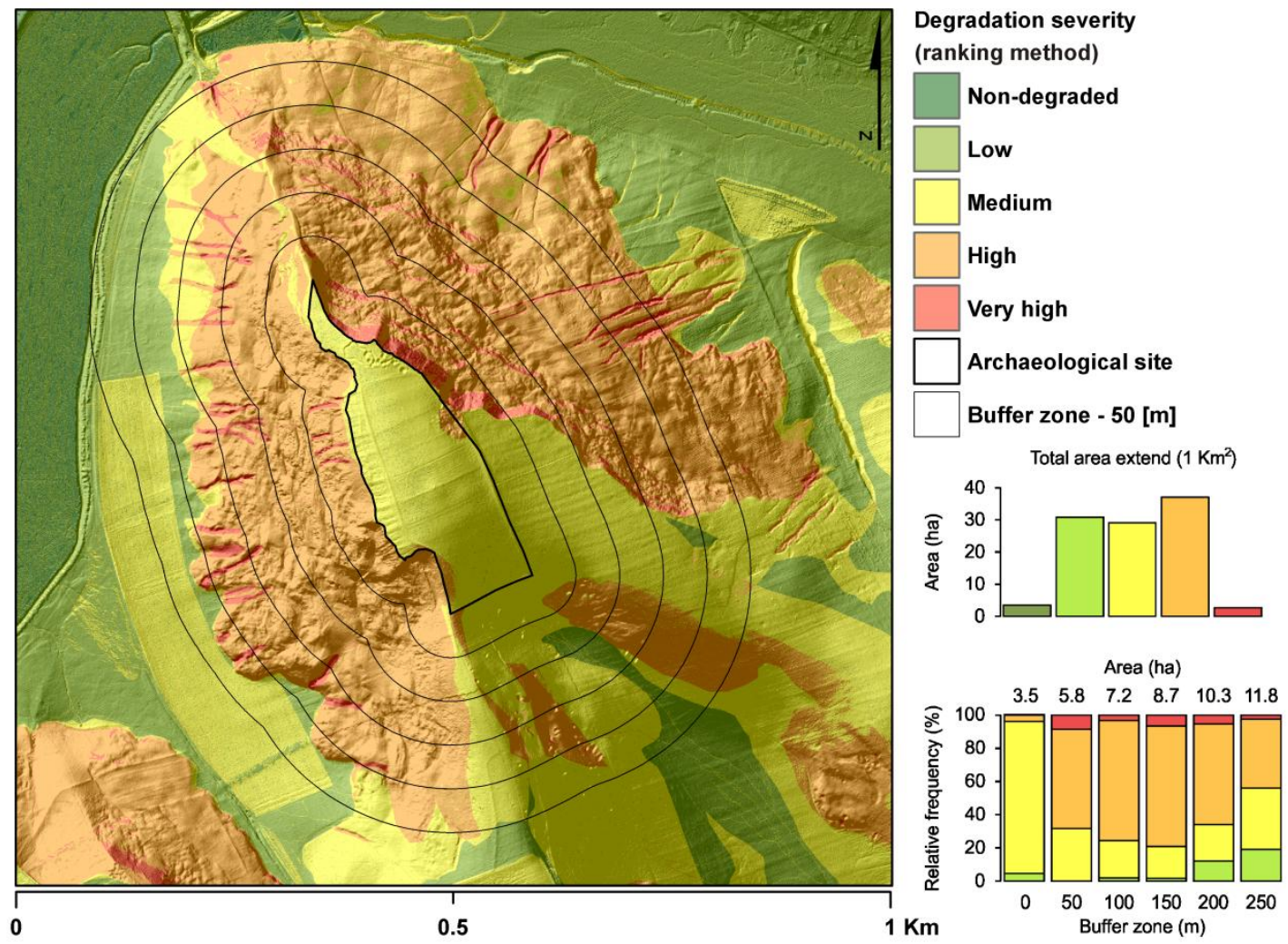

Figure 3: Degradation severity map of Dealul Mare archaeological site

The protective natural layer integrates the soil cover and the vegetation. As a general rule, the prehistoric archaeological sites located in NE of Romania have an average vertical distribution from the topographical surface level of 1-2 m, and are embedded in the soil layer by pedogenetical processes. In this case, the protection level of archaeological materials are complementary with the susceptibility of soils to be eroded. The most important role belongs both the soil texture and relationship between texture fractions that influence a variety of physical and hydric soil processes. In case of soil types described by a balanced texture, the erosion has a minimum value, and in case of soils with coarse or fine texture, the erosion increases in direct ratio with the sand/clay ratio [8 and 9]. The maximum potential value concerning soil erosion in the area of the archaeological site is 5 ( $\mathrm{CH}$ ca eroaded) and holds $47.93 \%$ of the studied area. The natural conservation of archaeological sites is strongly influenced by land use or vegetation coverage. Thus, the evaluation of this parameter was performed based on the drain coefficients which are dependent with the land use. [9] Among all land use 
categories, the strongest potential for soil erodability is specific to degraded pastures, which in the site area occupy $40.38 \%$ of the total.

The destructive context, in which the archaeological sites are located, is specific to each area separately, while the degree of degradation is related to: landform, actual geomorphological processes, vertical amplitude and horizontal distribution, the age of archaeological materials and typology of site, the degree of anthropogenic intervention etc. Thus it can delimitate two categories of processes that lead to the degradation of immovable cultural heritage: natural erosion processes and anthropogenic interventions. In the category of natural factors are included: sheet and rill erosion, gully erosion and landslides. Of these, the geomorphological elements, with highest destructive potential, scarps $(5.6 \%)$ and gully $(2.91 \%)$. From the anthropogenic interventions category, the areas that contain archaeological materials, the most of them are related to the location where there are settlements, farming or the exploitation of natural resources. Beside of these, the activity of human society potentiates the natural erosion by selective extraction methods of archaeological materials. For example, in the Dealul Mare site, the excavations that remain unclosed intensify the soil erosion, and the area affected is 0.09 ha. To these are added 0.27 ha affected by bomb craters and trenches military from WWII.

The hydrogeomorphic and human impact risks map that currently affecting the Dealul Mare archaeological site, reveals the involvement of all thematic layers introduced in computing the geoformula. The classes distribution of degradation severity according to ranking method is: non-degraded (3.42 ha); low (30.85 ha); medium (29.08 ha); high (37.13 ha); very high (2.68 ha). The mean values of degradation severity occupy the structural plateau, where the most part of the archaeological site is located. The high values of degradation severity characterize slopes with intense geomorphological processes such as landslides and deep erosion. The highest values correspond with active scarps and ravines' thalweg, which generate a strong erosion over archaeological materials (Fig. 3).

For a more detailed overview, over the processes that affecting the integrity of the site, was carried out an analysis of the severity of damage using $50 \mathrm{~m}$ buffer zone around the settlement. Therefore, whithin the site area ( $0 \mathrm{~m}$ buffer zone) the degradation is medium (91.5\%). Whithin the $50 \mathrm{~m}$ buffer zone, the dominant degradation severity classes are "medium" (31.6\%) and "high" (59.8\%). The "very high" class occupies around 8.5\% of the site, that highlights the active escarpments which accelerate the erosion.

\section{CONCLUSIONS}

The risk of destruction of archaeological inventory due to erosion, is a present-day threat on Moldova Plateau. To natural factors the anthropogenic pressure exerted by human activity is added. Extracting the spatial information and interpolating cumulative of thematic layers in GIS, can be an effective method for assessing the degradation of archaeological sites. The hydro-geomorphological and anthropogenic pressures map, faced by areas that hold archaeological relicts, can be used to quantify their vulnerability and may underlie the actions of rescue and / or preserving the natural context. 
ACKNOWLEDGMENTS: This work was supported by the Romanian National Research Council, through the program Partnership in Priority Domains, project PN-IIPT-PCCA-2013-4-2234, 314/2014 - Non-destructive approaches to complex archaeological sites. An integrated applied research model for cultural heritage management [12]

\section{REFERENCES}

[1] Nicu, I.C. Hydrogeomorphic risk analysis affecting Chalcolithic archaeological sites from Valea Oii (Bahlui) watershed, Northeastern Romania. An interdisciplinary approach. Book, Springer International Publishing, DOI: 10.1007/978-3-319-25709-9, 2016.

[2] Nicu, I.C. \& Romanescu, G. Effect of natural risk factors upon the evolution of Chalcolithic human settlements in Northeastern Romania (Valea Oii watershed). From ancient time dynamics to present day degradation. Zeitschrift für Geomorphologie NF, Germany, vol. 60, pp 1-9, 2016.

[3] Mihu-Pintilie, A. \& Romanescu, G. Determining the potential hydrological risk associated to maximum flow in small hydrological sub-basin with torenttial character of the river Bahlui. Present Environment and Sustainable Development, Romania, vol. 5(2), pp 255-266, 2011.

[4] Nicu, I.C. \& Mihu-Pintilie, A. Hydro-geomorphological risk analysis models in experimental river basins. Case study: Băiceni-Cucuteni Museum gully (Oii Valley watershed). Lucrările Seminarului Geografic "Dimitrie Cantemir", Romania, vol. 34, pp 15-22, 2012.

[5] Asăndulesei A., Nicu, I.C., Balaur, R., Caliniuc, Ș., Asăndulesei, M. \& Cotiugă, V. Integrated prospection methods for documenting threatened prehistoric archaeological sites from north-eastern Romania. Archaeologia Polona, Poland, vol. 53, pp 425-430, 2015.

[6] SMIS-CSNR 32193: Planul pentru prevenirea, protecția și diminuarea efectelor inundațiilor în bazinul hidrografic Siret, ANAR - Administraţia Bazinală de Apă Siret, Romania.

[7] SMIS-CSNR 17945: Lucrări pentru reducerea riscului la inundaţii în bazinul hidrografic Prut-Bârlad, ANAR - Administraţia Bazinală de Apă Prut-Barlad, Romania.

[8] Pîrnău, R.G., Mihu-Pintilie, A., Bodi, G. \& Asăndulesei, A. Ground Penetrating Radar as noninvasive method used in soil science and archaeology. Soil Forming Factors and Processes from the Temperate Zone, Romania, vol. 13, pp 15-32, 2015.

[9] Florea, N., Bălăceanu, V., Răuță, C. \& Canarache A. Metodologia elaborării studiilor pedologice. Indicatorii ecopedologici. Book, Institutul de Cercetări Pedologice și Agrochimice, Romania, vol. 20C, 1987.

[10] Mărgărint, M.C., Grozavu, A. \& Patriche C.V. Assessing the spatial variability of coefficients of landslide predictors in different regions of Romania using logistic regression. Natural Hazards and Earth System Sciences, vol. 13, pp 3339-3355, 2013. 
[11] Yahaya S. Multicriteria analysis for flood vulnerable areas in Hadejia-Jama'are river basin, Nigeria. Proceedings of ASPRS Annual Conference, Bridging the Horizons: New frontiers in Geospatial Collaboration, Portland, Oregon, 28 april - 2 may 2008.

[12] arheoinvest.uaic.ro/ research/prospect 